\title{
DOI https://doi.org/10.30525/978-9934-26-116-9-22
}

\section{ПРОБЛЕМИ РЕАЛІЗАЦІЇ ПРЕЗИДЕНТСЬКОЇ СТРАТЕГІЇ РОЗВИТКУ СИСТЕМИ ПРАВОСУДДЯ}

\author{
Георгісвський Ю. В. \\ доктор юридичних наук, дочент, \\ завідувач наукового відділу правового забезпечення галузевого \\ інноваційного розвитку Науково-дослідного інституту правового \\ забезпечення інноваційного розвитку \\ Національної академії правових наук України, \\ доцент кафедри адміністративного права Начіонального юридичного \\ університету імені Ярослава Мудрого \\ м. Харків, Украӥна
}

11 червня 2021 року Президент України Володимир Зеленський своїм Указом № 231/2021 затвердив Стратегію розвитку системи правосуддя та конституційного судочинства на 2021 - 2023 роки (далі за текстом - Стратегія), в якій зазначив, що незалежне та неупереджене правосуддя є запорукою сталого розвитку суспільства і держави, гарантією додержання прав і свобод людини та громадянина, прав та законних інтересів юридичних осіб, інтересів держави, зростання добробуту та якості життя, створення привабливого інвестиційного клімату, своєчасного, ефективного і справедливого вирішення правових спорів на засадах верховенства права [1].

Очевидно, що ця Стратегія є логічним продовженням політики Глави Держави щодо судової влади, задекларованої ним в попередніх програмних документах. Так, сприяння побудові миролюбного і відкритого суспільства в інтересах сталого розвитку, забезпечення доступу до правосуддя для всіх і створення ефективних, підзвітних та заснованих на широкій участі інституцій на всіх рівнях є однією 3 Цілей сталого розвитку України на період до 2030 року (пункт 16), які Президент України визначив в Указі від 30 вересня 2019 року № 722/2019 [2]. Нагадаємо, що таку ціль Глава Держави визначив в якості одного з орієнтирів для розроблення проєктів прогнозних і програмних документів, проєктів нормативно-правових актів 3 метою забезпечення збалансованості економічного, соціального та екологічного вимірів сталого розвитку України. Також удосконалення законодавства про організацію судової влади та забезпечення справедливого правосуддя, як один із засобів забезпечення сталого та динамічного 
економічного зростання, в подальшому Президент України визнав одним 3 основних напрямів зовнішньополітичної та внутрішньополітичної діяльності держави для забезпечення іiі національних інтересів і безпеки (пункт 53) в Стратегії національної безпеки України «Безпека Людини - безпека країни», яку Глава Держави затвердив своїм Указом від 14 вересня 2020 року № 392/2020 [3].

При цьому, аналіз змісту Стратегії дозволяє висловити певні зауваження, врахування яких дозволить ефективно спланувати роботу суб'єктів, відповідальних за іiі реалізацію, та зекономити час на удосконалення профільного законодавства. Так, у пункті 1 «Загальні положення» Розділу I «Розвиток системи правосуддя» Стратегії вказано, що вона визначає основні засади та напрями подальшого сталого функціонування та розвитку системи правосуддя з урахуванням кращих міжнародних стандартів та практик, пріоритети удосконалення положень законодавства у сфері судоустрою, статусу суддів, судочинства та інших інститутів правосуддя, а також впровадження невідкладних заходів для забезпечення позитивних зрушень у функціонуванні відповідних правових інститутів [1]. При цьому, деталізований перелік завдань, заходів, очікуваних результатів та показників подальшої реалізації реформи судоустрою, судочинства та інших правових інститутів в ній не міститься, а має відображатися у Плані дій щодо реалізації Стратегії, який додатково має схвалити Комісія 3 питань правової реформи.

Дійсно, Комісія з питань правової реформи (далі - Комісія) як консультативно-дорадчий орган при Президентові України з метою сприяння подальшому розвитку правової системи України на основі конституційних принципів верховенства права, пріоритетності прав i свобод людини і громадянина з урахуванням міжнародних зобов'язань України, що є їі основним завданням (пункт 3 Положення [4]), готує та узагальнює пропозиції стосовно законодавства про організацію судової влади, здійснення правосуддя та статус суддів підпункт 4 пункту 4 Положення [4]). Комісія вносить ці узгоджені пропозиції з питань вдосконалення правової системи України з урахуванням сучасних викликів та потреб демократичного суспільства Президентові України.

При цьому, Глава Держави в Указі про затвердження Стратегії не встановив ані строки розроблення та внесення Комісією Президентові України зазначеного Плану дій щодо реалізації Стратегії, ані надав доручення Кабінетові Міністрів України щодо визначення механізму впровадження такого Плану. Не міститься в Указі конкретних строків інформування Комісією Президента України про стан реалізації положень Стратегії та строків проведення Комісією публічного 94 
обговорення результатів реалізації Стратегії за попередній рік. Також не зрозуміло, як узгоджуватимуться пропозиції Комісії 3 питань правової реформи із законопроєктною роботою інших суб'єктів законодавчої ініціативи та порядком денним сесій Верховної Ради України.

На нашу думку, така невизначеність у сукупності 3 короткостроковим періодом запровадження позбавляє можливості оцінювати такий документ як стратегічний, надаючи йому здебільшого декларативний характер.

Отже, нам уявляється за доцільне корегування Главою Держави Указу про затвердження Стратегії та надання ним відповідних доручень та строків їх виконання, зокрема, Комісії з питань правової реформи (з розроблення Плану дій щодо реалізації Стратегіi) та Урядові України - щодо визначення механізму впровадження такого Плану. Внесення таких змін сприятиме формуванню дієвого механізму реалізації Стратегії розвитку системи правосуддя та конституційного судочинства на $2021-2023$ роки.

\section{Література:}

1. Про Стратегію розвитку системи правосуддя та конституційного судочинства на 2021 - 2023 роки : Указ Президента України від 11 червня 2021 року № 231/2021. URL.: https://www.president.gov.ua/ documents/2312021-39137 (дата звернення 02.07.2021).

2. Про Цілі сталого розвитку України на період до 2030 року : Указ Президента України від 30 вересня 2019 року № 722/2019. URL.: https://www.president.gov.ua/documents/7222019-29825 (дата звернення 02.07.2021).

3. Про рішення Ради національної безпеки і оборони України від 14 вересня 2020 року «Про Стратегію національної безпеки України» : Указ Президента України від 14 вересня 2020 року № 392/2019. URL.: https://www.president.gov.ua/documents/3922020-35037 (дата звернення 02.07.2021).

4. Питання Комісії 3 питань правової реформи : Указ Президента України від 7 серпня 2019 року № 584/2019. URL.: https://zakon.rada.gov.ua/laws/show/584/2019\#Text (дата звернення 02.07.2021). 